\title{
THE EFFECT OF THE REPRODUCTIVITY'S VELOCITY ON THE BIODIVERSITY OF A THEORETICAL ECOSYSTEM
}

\author{
HufNAGEL, L. ${ }^{1}$ - DRÉGELYI-KISS, G. ${ }^{2}$ - DRÉGELYI-KISS, A. ${ }^{3 *}$ \\ ${ }^{I}$ „Adaptation to Climate Change" Research Group of the Hungarian Academy of Sciences \\ H-1118 Budapest, Villányi út 29-43, Hungary \\ (phone: +36-1-482-6261; fax: +36-1-466-9273) \\ ${ }^{2}$ University of Pécs, Pollack Mihály Faculty of Engineering, \\ Department of Environmental Engineering \\ H-7624 Pécs, Boszorkány u. 2, Hungary \\ (phone: +36-72-503-650/3958; fax: +36-72-503-650/3965) \\ ${ }^{3}$ Óbuda University, Bánki Donát Faculty of Mechanical and Safety Engineering \\ H-1081 Budapest, Népszínház u. 8., Hungary \\ (phone: +36-1-666-5332; fax: +36-1-666-5480) \\ *Corresponding author \\ e-mail: dregelyi.agota@bgk.uni-obuda.hu \\ (Received $27^{\text {th }}$ February 2010 ; accepted $30^{\text {th }}$ April 2010)
}

\begin{abstract}
Climate change has a great impact on the build and the work of natural ecosystems. Disappearance of some population or growth of the number in some species can be already caused by little change in temperature. A Theoretical Ecosystem Growth Model was investigated in order to examine the effects of various climate patterns on the ecological equilibrium. This paper examines the diversity of a theoretical ecosystem on the grounds of changing in temperature-climate patterns.

Simulations were made from the simplest case to the more complex exercise to explain harder questions. Daily temperature values were calculated according to various functions. The effect of existing climate patterns (historical or future daily temperatures) was analysed where temperature values were from various climatic zones. In this paper it is examined what kind of environmental conditions result larger diversity related to the velocity of reproduction.
\end{abstract}

Keywords: analogous places; climate change; climate modelling; diversity; ecosystem.

\section{Introduction}

There are several consequences of the decrease in biodiversity. The most scenic is the decrease in the number of species. Secondly the decrease in genetic diversity has to be mentioned, there are a lot of cases where stands of the frequent species decrease. At the third case the contents of ecosystems change also, the various habitats allow of being and maintenance of creatures between different geological and climatic conditions. This kind of role of ecosystems is less known (Nechay, 2002).

At natural ecological systems there is dinamic equilibrium between the climate and ecosystems. If the system is affected a response starts in order to maintain the equilibrium. The degree of this reaction could be a sudden response by leaps or on the other hand gradual. Some variables such as the phenological properties follow the changing climatic conditions simply; in these cases gradual shifts could be expected (Fitter et al., 2002). In case of sudden responses there is a good example in the maritime tidal zone where the community significantly alters under small-scale temperature 
increase, which is caused by drastic decrease in the number of dominant predators (Sanford, 1999).

According to the forecasts the probability of extreme weather conditions will increase which increase further the occurence of sudden effects. There are some quick extreme events and the given sudden responses behind the events which seemed to have experienced gradual changes (Easterling et al., 2000).

In case of climate change this is not about the shift of the system being in equilibrium, but the succession could break or unhoped-for steps occur. In a mediterrenean scrub regenerated after a fire the number of species does not change under artificial drought-treating while the number of species increases in the control parcel fluently (Penuelas et al., 2007). The reaction of the run-down, degrading and regenerated communities for the climate change differs significantly from the reaction of natural ecosystems. These processes are important because there are much more of these areas like naturals (Czucz et al., 2007).

The hypothetic-centred approaches of researches there are three types:

- testing simple hypotheses with laboratory or field experiments (e.g. fitotron palnt growing room)

- analysing given ecosystems with tactical models (Sipkay et al., 2008; 2009; Vadadi-Fülöp et al., 2008a; 2008b; Eppich et al., 2009)

- examinations of general questions with strategic modeling (Drégelyi-Kiss and Hufnagel, 2009)

Some results have been reached in analysing the effect of some temperature-climate patterns on the production and community ecological relations in a strongly simplified theoretical model (Drégelyi-Kiss and Hufnagel 2009, 2010). The novelty of this modeling is characterized by a guild-specific approach at first (where competitive relationships can be manifested), on the other hand the population-dinamic model has been connected with the outputs of global circulation models. So this connection enables us to examine directly the effects of climate change. In this paper the various temperature effects are examined under changes in the diversity of a theoretical freshwater ecosystem:

- under constant temperature pattern with random fluctuations,

- under annual temperature fluctuations,

- under real, various climate temperature patterns (for historical and forecasted data).

\section{Materials and methods}

\section{Theoretical Ecosystem Growth Model (TEGM)}

An algae community consisted of 33 species in a terrestrial freshwater ecosystem is modelled (Drégelyi-Kiss and Hufnagel, 2009). Algae species are characterized by the temperature interval in which they are able to reproduce. There are four types of species based on their sensitivity: super-generalists (SG), generalists (G), transitional species (T) and specialists (S).

The reproductive feature depends only on their temperature sensitivity and a restrictive function has been built which is related to the access of sun (the period of the function is 365.25 , the maximum place is on $23^{\text {rd }}$ June and the minimum place is on $22^{\text {nd }}$ December).

APPLIED ECOLOGY AND ENVIRONMENTAL RESEARCH 8(2): 119-130. http://www.ecology.uni-corvinus.hu • ISSN 15891623 (Print) • ISSN 17850037 (Online) (c) 2010, ALÖKI Kft., Budapest, Hungary 
The examined temperature range corresponds to the temperature variation in the temperate zone. Thirty-three algae species with various temperature sensitivity can be seen in the Fig. 1. The daily reproductive rate of the species can be seen on the vertical axis, which means by how many times the number of specimens can increase on a given temperature. This corresponds to the reproductive ability of freshwater algae in the temperate zone (Reynolds, 2006; Sipkay et al., 2007).

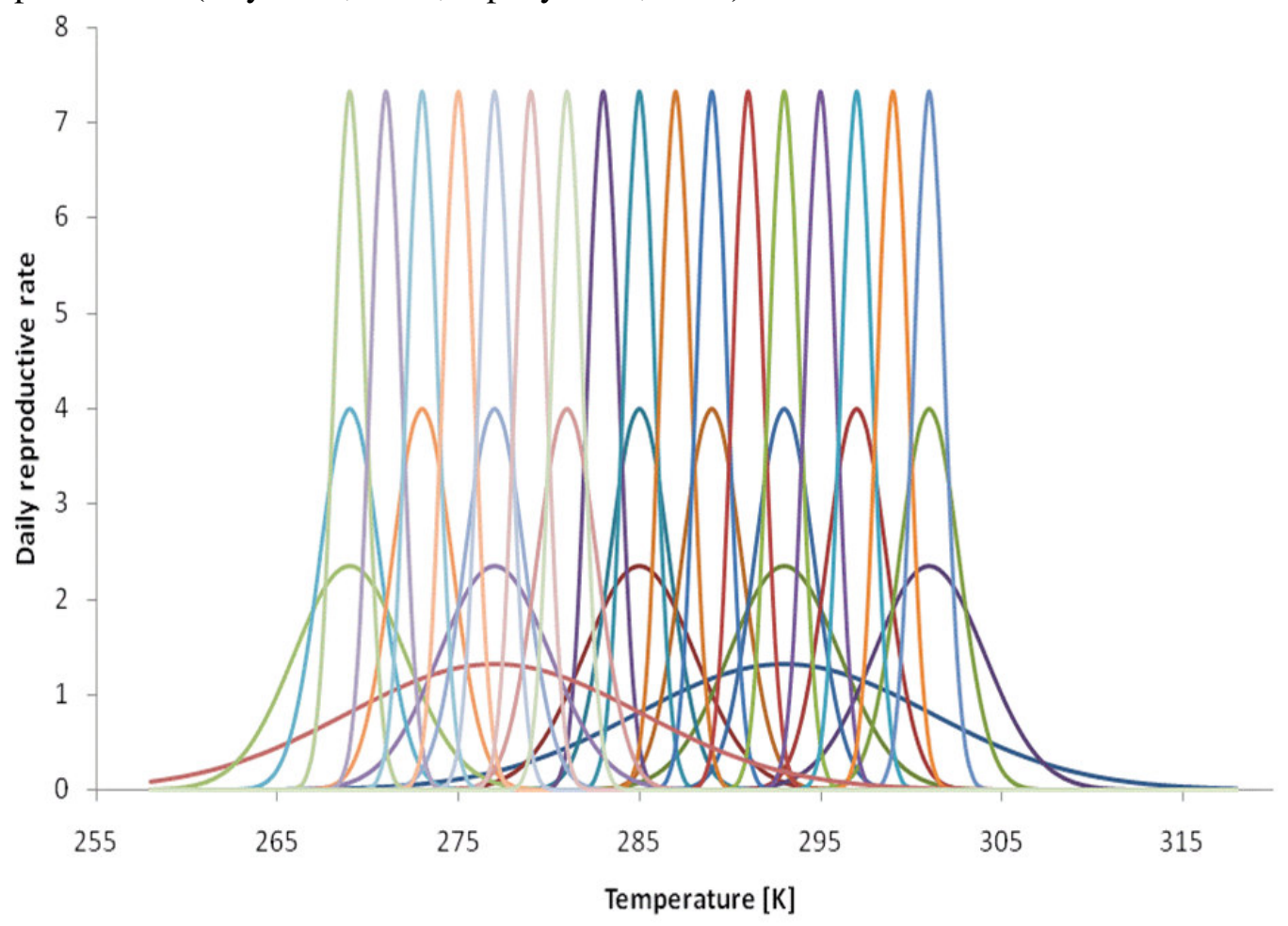

Figure 1. Reproductive temperature pattern of 33 algae species

Among the parameters of the TEGM model a velocity parameter exists, the velocity of the reproductivity of the ecosystem can be set up. During our experiments this value has been examined in two level ( $r=1$ in case of faster, $r=0.1$ in case of lower reproducibility).

In our experiments the distribution of the algae community of a theoretical freshwater ecosystem has been examined by changing the temperature. Competition begins among the species when the temperature changes. In each temperature interval there are dominant species, which win the competition. The temperature was changed systematically in order to be able to estimate the various effects separately. The duration of the simulation was usually 10 years in the experiments. Measuring the diversity the Shannon diversity function was used (Hammer et al., 2009; Jost, 2006; Tóthmérész, 1997; 2001).

\section{Functions of temperature patterns}

The daily values of the temperature were determined in several ways. At first the effect of the constant temperature pattern is examined on the composition of the theoretical ecosystem, then the consequences of the annual temperature fluctuation modelled by sine function. Finally, the effects of existing climate patterns is calculated. 
The stream of the daily temperature average values is cyclic therefore the used temperature data series is described by appropriate functions.

\section{Constant temperature}

Simulation experiments were made on $293 \mathrm{~K}, 294 \mathrm{~K}$ and $295 \mathrm{~K}$ with the two velocity parameters $(\mathrm{r}=1$ and 0.1$)$. Fluctuation was added as $\pm 1 \ldots \pm 11 \mathrm{~K}$ random numbers.

\section{Sine temperature pattern in a year}

Annual average temperature of Budapest is about 283-284 K (between 1960 and 1990), the range of temperature data is between $30 \mathrm{~K}$ and $45 \mathrm{~K}$. The following function describes this temperature pattern (with a day period of 365.25):

$$
T=s_{1} \cdot \sin \left(s_{2} \cdot t+s_{3}\right)+s_{4}
$$

where $s_{2}=0.0172, s_{3}=-1.4045$. During the experiments the height $\left(s_{1}\right)$ and the place $\left(s_{4}\right)$ of the sine function can be modified. The $s_{1}$ value is between $15 \mathrm{~K}$ and $22.5 \mathrm{~K}$ and $s_{4}$ is equal to $284 \mathrm{~K}$ according to the Budapest historical data.

\section{Existing climate patterns (historical and future)}

One of the parameters used for describing the climate is the daily average temperature value. This means a great deal of numbers for long term (30 years) examinations: $30 \times 365$ values. In order to simplify the description of the climate and to ignore the fluctuation between years a function has been fitted to averages and dispersion of the 30 years' data according to the least squares method. It is found that the daily average temperature from various climate zones fluctuates according to the following function (deterministic term):

$$
T(t)=a_{1} \sin \left(a_{2} \cdot t+a_{3}\right)+a_{4}+a_{5} \sin \left(a_{6} \cdot t+a_{7}\right)
$$

The standard deviation of the daily average temperature during the 30 years can be described by the next function (stochastic term):

$$
s(t)=b_{1} \sin \left(b_{2} \cdot t+b_{3}\right)+b_{4}
$$

The daily average temperature values can be classified according to their origin: historical or future. For these data series daily temperature values can be generated with the following expression:

$$
\text { Generated }(t)=\operatorname{average}(t)+(3,5 \cdot \operatorname{Rnd}()-1,75) \cdot s(t)
$$

where $t$ is the number of the year, Rnd() is a random value between 0 and 1 .

The classification of the used existing climate patterns is the following:

- Historical temperature values from 1960 to 1990 in Hungary (Budapest)

- Historical international data from various climate zones (according to KöppenGeiger classification (Peel et al., 2007))

Daily average temperature data were collected with the help of web database (Klein Tank et al., 2002) from the following cities all over the world. (In some meteorological stations there were not any available historical data for 30 years, only from 1995 till 2008)

i.Tropical climate (Bangui $4^{\circ} 22^{\prime}$ N $18^{\circ} 35^{\prime}$ E, Central African Republic)

ii.Dry climate (Taskent $35^{\circ} 16^{\prime} 15^{\prime \prime} \mathrm{N}, 33^{\circ} 23^{\prime} 30^{\prime \prime} \mathrm{E}$, Cyprus)

iii.Temperate climate (Den Helder $51^{\circ} 25^{\prime} 60^{\prime \prime} \mathrm{N}$, $4^{\circ} 31^{\prime} 60^{\prime \prime}$ E, The Netherlands)

iv.Continental climate (Ulan Bator $47^{\circ} 55^{\prime} 0$ " N N, 106 55' 0" E, Mongolia)

v.Polar climate (Sodankyla, $67^{\circ} 25^{\prime} 00^{\prime \prime}$ N, 26³5’35” E, Finland)

APPLIED ECOLOGY AND ENVIRONMENTAL RESEARCH 8(2): 119-130. http://www.ecology.uni-corvinus.hu • ISSN 15891623 (Print) • ISSN 17850037 (Online) (C) 2010, ALÖKI Kft., Budapest, Hungary 
A place has been chosen from the main climate zones and the change in the composition of our theoretical ecosystem has been examined.

- Future temperature patterns from 2070 to 2100 in Hungary

i. Hadley Center adhfa (Regional Model 3, SRES A2)

ii. Hadley Center adhfd (Regional Model 3, SRES B2)

iii. MPI 3009

- Analogous places in Hungary by 2100 (Hufnagel et al., 2008)

It is predicted that the climate in Hungary will become the same which is the present day climate on the border of Romania and Bulgaria or near Thessaloniki. According to the worst prediction the climate will be like the current NorthAfrican climate. Therefore the following places have been examined:

i. $\quad$ Turnu Magurele, Romania $\left(43.75^{\circ} \mathrm{N}, 24.88^{\circ} \mathrm{E}, 31.0 \mathrm{~m}\right)$

ii. Cairo, Egypt $\left(30.058^{\circ} \mathrm{N}, 31.229^{\circ} \mathrm{E}\right)$

Scenarios of analog places are simple because temperature is the only factor which has been considered.

\section{Results}

\section{Constant temperature}

There is larger change in diversity in case of lower velocity parameter while smaller change in the other case which has higher velocity parameter (Table 1). The diversity value of the ecosystem is strongly affected by the setting temperature value and the random fluctuation. The largest diversity value has been reached when the temperature is not an optimum of a genus for reproduction (294 K).

With the increase of fluctuation the diversity value becomes a low value, but there is one order of magnitude difference in diversity between the processes come from the slower and the faster reproduce-able ecosystems.

In case of largest fluctuation $( \pm 11 \mathrm{~K})$ the degree of the diversity increases significantly.

Table 1. Shannon diversity values in case of constant temperature patterns and various random fluctuations

\begin{tabular}{c|c|c|c|c|c|c}
\hline & \multicolumn{3}{|c|}{$\mathbf{r = 1}$} & \multicolumn{3}{c|}{$\mathbf{r}=\mathbf{0 . 1}$} \\
\hline Fluctuation [K] & $\mathbf{2 9 3} \mathbf{~ K}$ & $\mathbf{2 9 4} \mathbf{K}$ & $\mathbf{2 9 5} \mathbf{K}$ & $\mathbf{2 9 3} \mathbf{K}$ & $\mathbf{2 9 4} \mathbf{K}$ & $\mathbf{2 9 5} \mathbf{K}$ \\
\hline 0 & 0.0244 & 0.8860 & 0.0002 & 0.0569 & 1.0080 & 0.0010 \\
\pm 1 & 0.0429 & 0.0001 & 0.0001 & 0.1180 & 0.0285 & 0.0003 \\
\pm 2 & 0.0001 & 0.0000 & 0.0000 & 0.0302 & 0.4224 & 0.0034 \\
\pm 4 & 0.0000 & 0.0000 & 0.0000 & 0.0000 & 0.0000 & 0.6575 \\
\pm 7 & 0.0000 & 0.0000 & 0.0000 & 0.0000 & 0.0000 & 0.0000 \\
\pm 11 & 1.4920 & 1.6670 & 1.2210 & 0.9243 & 1.1530 & 2.7620 \\
\hline
\end{tabular}

\section{Sine temperature pattern in a year}

The experiments - in case of $r=1$ - were run until that degree of fluctuation where the annual average use of resources was higher than $0.1 \%$. With the increase of random fluctuation the annual total number of specimens and the composition of species in consecutive years better and better differ from each other.

In case of $s_{1}=0$ with $r=0.1$ velocity factor (which is equal to the $284 \mathrm{~K}$ constant temperature) the species have already disappeared at $\pm 7 \mathrm{~K}$ random fluctuation. This was 
not observed under $293-295 \mathrm{~K}$ constant temperature, where this has occurred at $\pm 11 \mathrm{~K}$ random fluctuation.

It can be seen in Fig. 2 and 3 how the annual total number of specimens changes in function of daily random $(0 \ldots \pm 7 \mathrm{~K})$ and the annual fluctuation $\left(s_{1}\right.$, the amplitude of sine function). The two fluctuations result that the number of specimens and the use of resources is low already at $\pm 7 \mathrm{~K}$ random fluctuation.

The maximum value in annual total number of specimens is reached in case of $r=1$ velocity parameter and $s_{1}>15$. The maximum annual total number of specimens related to the $r=0.1$ process is reached at low annual fluctuation $\left(s_{1}=0,2\right)$.

Regarding the diversity of the ecosystem there are opposite trends in case of ecosystems which have different velocity parameters. It can be seen in Fig. 4 and 5 that the ecosystem which has faster reproduction has low diversity values at constant temperature and with $s_{1}=2$ parameter except for the case which has no daily random fluctuation. The values of Shannon diversity in case of greater annual random fluctuation (with parameters $s_{1}>5$ ) are in inverse proportion with the increase of daily random fluctuation.

In case of ecosystems which have slower reproduction the diversity is in direct proportion with the function of random daily fluctuation after a short decrease. The diversity values are smaller in case of ecosystems which have $r=1$ parameter.

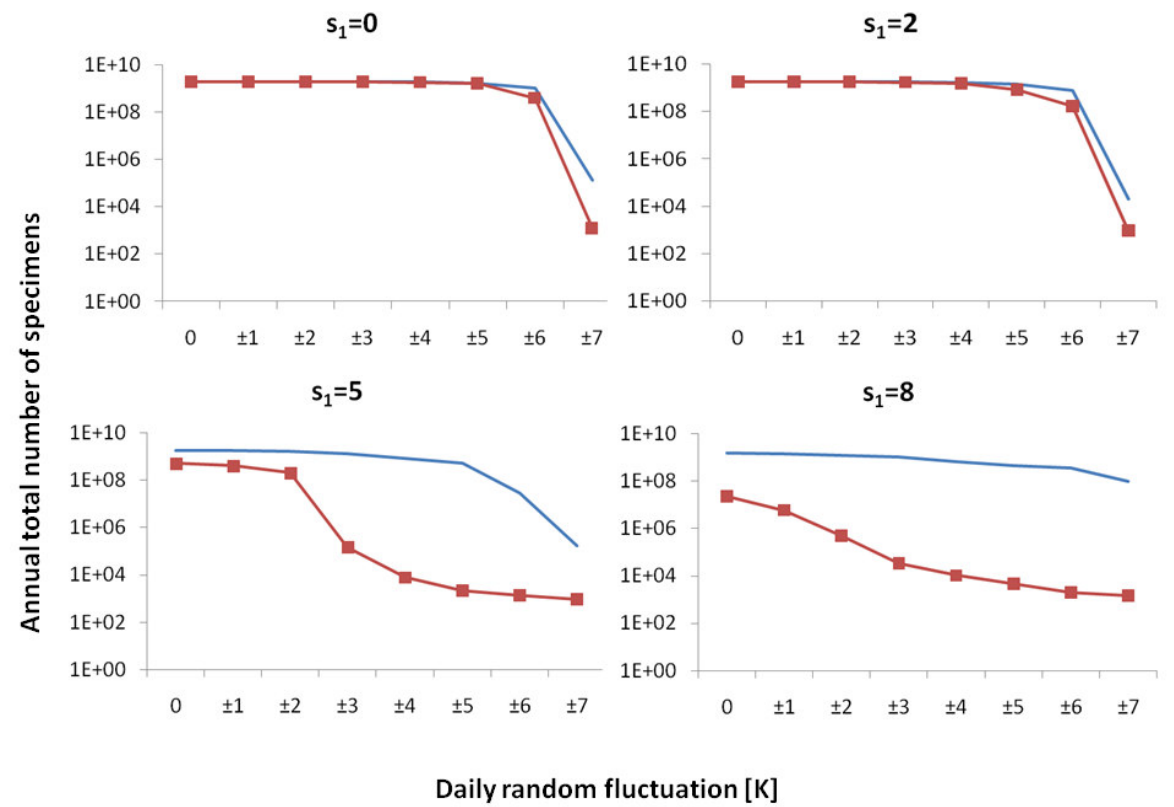

Figure 2. Annual total number of specimens versus the daily random fluctuation in sine temperature environment for low $s_{1}$ parameters (The square-signed data series show the processes with $r=0.1$ velocity parameter and the non-signed is related to the other setting, $r=1$ ) 


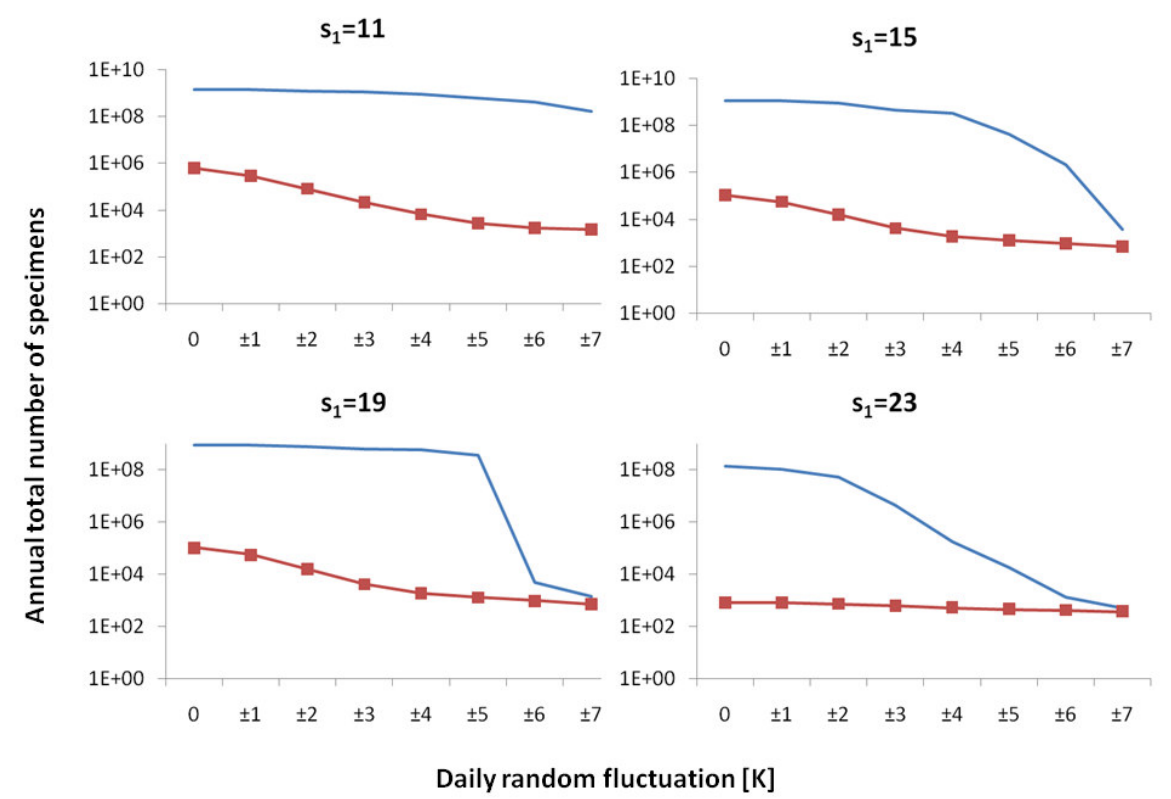

Figure 3. Annual total number of specimens versus the daily random fluctuation in sine temperature environment for high $s_{1}$ parameters (The square-signed data series show the processes with $r=0.1$ velocity parameter and the non-signed is related to the other setting, $r=1$ )



Figure 4. Shannon diversity values versus the daily random fluctuation in sine temperature environment for low $s_{1}$ parameters (The square-signed data series show the processes with $r=0.1$ velocity parameter and the non-signed is related to the other setting, $r=1$ ) 


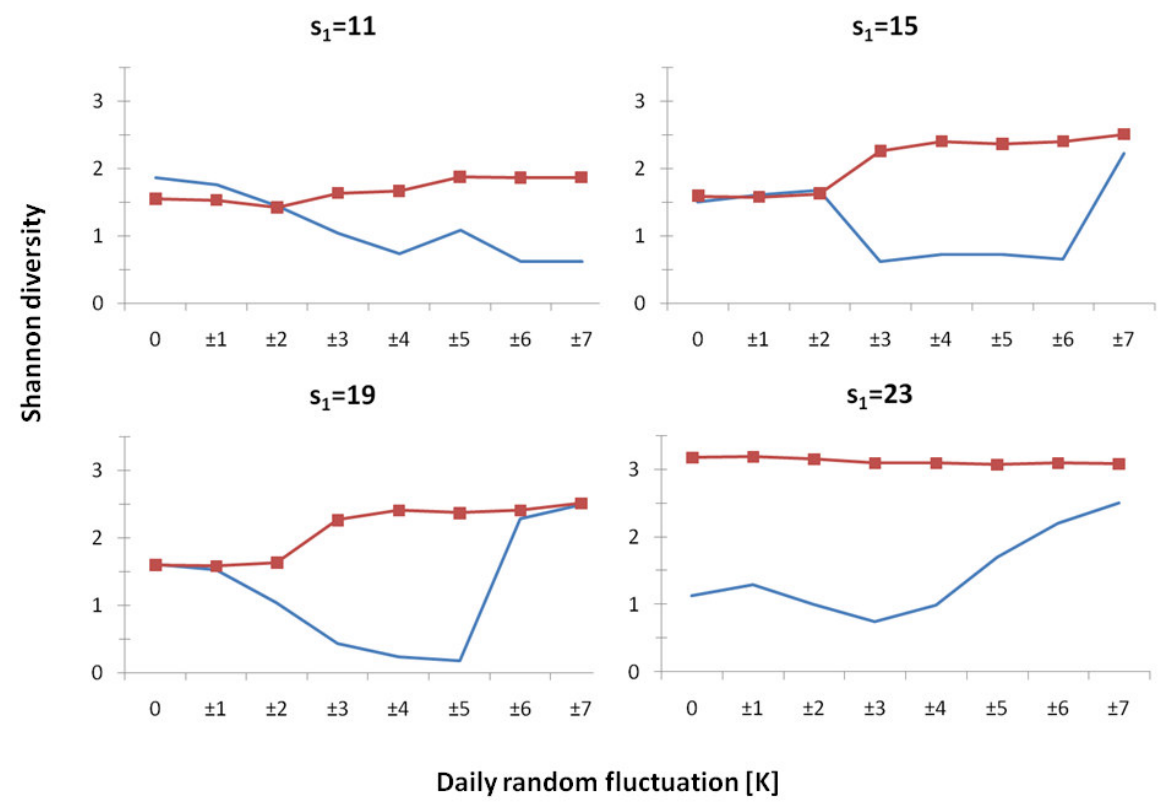

Figure 5. Shannon diversity values versus the daily random fluctuation in sine temperature environment for high $s_{1}$ parameters (The square-signed data series show the processes with $r=0.1$ velocity parameter and the non-signed is related to the other setting, $r=1$ )

\section{Existing climate patterns}

The annual total number of specimens and the diversity values for various climate conditions are presented in Fig. 6. The simulation has been repeated 10 times, therefore the averages of the characteristics and the calculated deviation for the diversity values can be seen in graph.

Regarding the annual total number of specimens it is stated that the species are in maximum numbers in case of ecosystems which has faster reproduction. There is only one climate condition (Bangui) where the maximum value in the number of specimens has been reached in case of slower reproduction. The difference between the annual total number of specimens in cases $r=1$ and $r=0.1$ is the largest at climate pattern of Ulan Bator.

The reproduction of the simulated experiments is sufficient in most cases.

The diversities are between 1.5 and 2.5 in case of $r=1$ velocity parameter except for the case of Bangui which has 0 diversity value. 


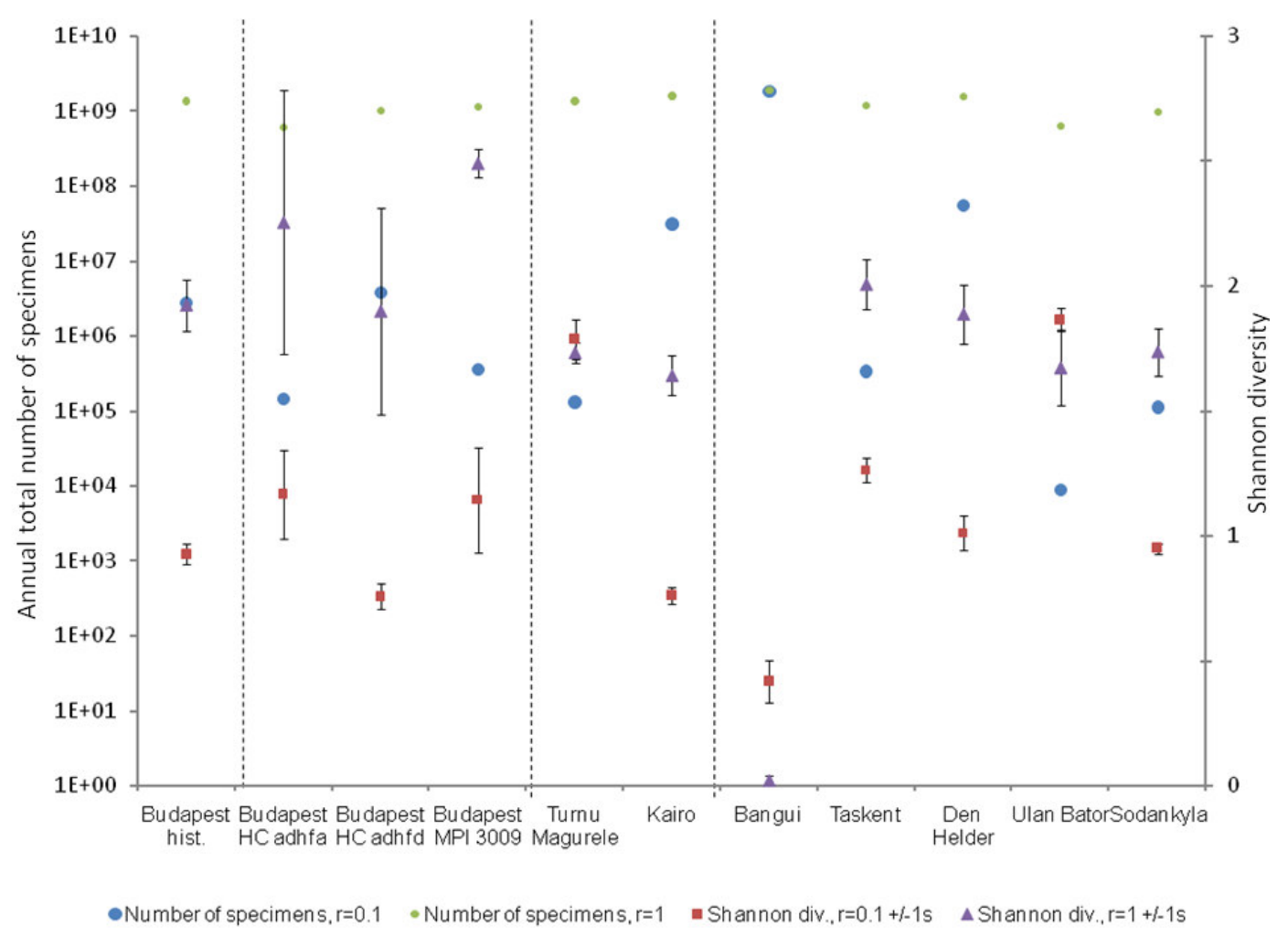

Figure 6. The average of annual total number of specimens and diversity values in case of various climate conditions (10 repeated simulations, \pm 1 s are shown regarding the diversity values)

\section{Discussion}

Initially the community tries to adapt to its environment and many genre compete for the environmental elements with large number of specimens. In case of large noise the diversity is large and the annual total number of specimens is low, because a few genres could adapt to the environmental conditions.

Analysing peaks evolved at constant temperature patterns and with $r=0.1$ velocity parameter it is stated, that the largest biodiversity values exist in case of medium disturbance, the Intermediate Disturbance Hypothesis (Connell, 1978; Elliott et al., 2001) could be observed.

In case of sine temperature patterns there is a strong connection between the number of specimens and the velocity parameters hence $r=0.1$-characterized ecosystems have low number of specimens. There is huge difference between the number of specimens values for cases $r=1$ and $r=0.1$. In ecosystems having $r=0.1$ velocity parameter there are larger diversity and smaller number of specimens, namely the specimens of the community belong to different genus.

Irrespectively of velocity parameter the largest number of specimens is in case of the smallest amplitude $\left(s_{1}=2\right)$ and the diversity is small, namely a few genre occur with large number of specimens. This could be observed similarly in tropical wet climate, Bangui, since the temperature fluctuation is small at the given climate. The genres which could adapted to the environment suppress the new arrivals, the principle of 
competitive exclusion prevails. Increasing the noise the biodiversity begins to grow, because the above-mentioned principle could not prevail here, since new genres occur continually.

Regarding the number of specimens the change is smaller in cases with $r=0.1$ velocity parameter - except for the temperature of Bangui. In diversity there are higher values in case of Ulan Bator and Turnu Magurele with $r=1$ than in case of lower reproduction.

In point of diversity functions there are lower values in case if $r=0.1$ parameter, while there are higher values with faster reproduction. There are a few exceptions such as Bangui (tropical wet climate), Ulan Bator (continental climate) and Turnu Magurele (analogous place with Hungary, Rumanian lowland).

Examining the responses of the real temperature patterns it is stated, that Bangui composes a separate group, it does not show any similarity with the other climatic environments. This is because Bangui lays on tropics, where nearly same temperature exists through the year, so the dominant species are able to reproduce.

During the various climate conditions the decrease in the number of specimens is reached earlier in case of slower reproduction than in the other case, and there are larger changes in diversity values. Generally it could be said that an ecosystem evolves finally with low number of specimens.

By the real climate functions it is stated, that from the predicted analogous places (Turnu Magurele, Romania; Cairo, Egypt, (Hufnagel et al., 2008)) Budapest shows similarity with Turnu Magurele in number of specimens and diversity values.

The specimens of the ecosystems do not only suffer the change in climate but they could affect the equilibrium of the biosphere or the composition of the air through the biogeochemical cycles. There is an opportunity to examine the controlling ability of temperature-climate with the theoretical ecosystem.

In our further research we would like to examine the effect of the ecosystem back to the climate (Dregelyi-Kiss et al., 2008). These temperature feedbacks have got a great emphasis related to DGVM models with large computation skills (Friedlingstein et al., 2006), but the feedbacks are not estimated directly. We would like to examine the process of the feedback with PC calculations to answer easy questions.

Acknowledgements. This research was supported by the "Bolyai János" Research Fellowship (Hungarian Academy of Sciences) and the Research Assistant Fellowship (Corvinus University of Budapest). This work was supported by HAS-CUB “Adaptation to Climate Change" Research Group and the research project of the National Development Agency TÁMOP 4.2.1.B-09/1/KMR-2010-0005.

\section{REFERENCES}

[1] Connell, J.H. (1978): Diversity in tropical rain forests and coral reefs. - Science New Series 199:1302-1310.

[2] Czucz B., Kroel-Dulay, Gy., Redei, T., Botta-Dukat, Z., Molnar, Zs. (eds) (2007): Éghajlatváltozás és biológiai sokféleség - elemzések az adaptációs stratégia tudományos megalapozásához. - Kutatási jelentés E-misszió Egyesület, Nyíregyháza [Climate change and biodiversity, Research Report].

[3] Drégelyi-Kiss, Á., Drégelyi-Kiss, G., Hufnagel, L. (2008): Ecosystems as climate controllers - biotic feedbacks (a review). - Applied Ecology and Environmental Research 6(2): 111-135.

APPLIED ECOLOGY AND ENVIRONMENTAL RESEARCH 8(2): 119-130. http://www.ecology.uni-corvinus.hu • ISSN 15891623 (Print) • ISSN 17850037 (Online) (C) 2010, ALÖKI Kft., Budapest, Hungary 
[4] Drégelyi-Kiss, Á., Hufnagel, L. (2009): Simulations of Theoretical Ecosystem Growth Model (TEGM) during various climate conditions. - Applied Ecology and Environmental Research 7: 71-78.

[5] Drégelyi-Kiss, Á., Hufnagel, L. (2010): Effects of Temperature-Climate Patterns on the Production of Some Competitive Species on Grounds of Modelling. - Environ Model Assess. doi: 10.1007/s10666-009-9216-4.

[6] Easterling, D.A. et al. (2000): Climate extremes: observations, modeling, and impacts. Science 289: 2068-2074.

[7] Elliott, J.A., Irish, A.E., Reynolds, C.S. (2001): The effects of vertical mixing on a phytoplanktoncommunity: a modelling approach to the intermediatedisturbance hypothesis. - Freshwater Biology 46: 1291-1297.

[8] Eppich, B., Dede, L., Ferenczy, A., Garamvölgyi, Á., Horváth, L., Isépy, I., Priszter, Sz., Hufnagel, L. (2009): Climatic effects on the phenology of geophytes. - Applied Ecology and Environmental Research 7: 253-266.

[9] Fitter, A.H., Fitter, R.S.R. (2002): Rapid changes in flowering time in british plants. Science 296: 1689-1691.

[10] Hammer, Ǩ., Harper, D.A.T., Ryan, P.D. (2009): PAST - Palaeontological STatistics, ver. 1.89, http://folk.uio.no/ohammer/past/past.pdf.

[11] Hufnagel, L .(ed) (2008): Klímaváltozás, biodiverzitás és közösségökológiai folyamatok kölcsönhatásai. - In: Harnos, Zs., Csete, L. (eds): Klímaváltozás: Környezet-KockázatTársadalom. Szaktudás Kiadó Ház, Budapest. pp. 275-300. [Climate change: Environment-Risk-Society].

[12] Jost, L.E. (2006): Entropy and diversity. - Oikos 113: 363-375.

[13] Klein Tank, A.M.G. coauthors (2002): Daily dataset of 20th-century surface air temperature and precipitation series for the European Climate Assessment. - Int. J. Climatol 22: 1441-1453.

[14] Nechay, G. (2002): A biológiai sokféleség csökkenése. - In: Pálvölgyi, T., Nemes, Cs., Tamás, Zs. (ed): Vissza vagy hova (Útkeresés a fenntarthatóság felé Magyarországon) Tertia, Budapest: 36-46 [Decrease in biodiversity].

[15] Peel, M.C., Finlayson, B.L., McMahon, T.A. (2007): Updated world map of the KöppenGeiger climate classification. - Hydrol. Earth Syst. Sci. 11: 1633-1644.

[16] Penuelas, J., Prieto, P., Beier, C., Cesaraccio, C., De Angelis, P., de Dato, G., Emmett, B.A., Estiarte, M., Gorissen, A., Kovács-Láng, E., Kröel-Dulay, Gy., Garadnai, J., Llorens, L., Pellizzaro, G., Riis-Nielsen, T., Schmidt, I.K., Sirca, C., Sowerby, A., Spano, D., Tietema, A. (2007): Response of plant species richness and primary productivity in shrublands along a north-south gradient in Europe to seven years experimental warming and drought. Reductions in primary productivity in the heat and drought year of 2003.Global Change Biology 13: 2563-2581.

[17] Reynolds, C. (2006): Ecology of phytoplankton. - Cambridge: Cambridge University Press.

[18] Sipkay, Cs., Hufnagel, L., Révész, A., Petrányi, G. (2007): Seasonal dynamics of an aquatic macroinvertebrate assembly (Hydrobiological case study of Lake Balaton, No. 2) - Applied Ecology and Environmental Research 5(2): 63-78.

[19] Sipkay, C., Horváth, L., Nosek, J., Oertel, N., Vadadi-Fülöp, C., Farkas, E., et al. (2008): Analysis of climate change scenarios based on modelling of the seasonal dynamics of a Danubian copepod species. - Applied Ecology and Environmental Research 6: 101-108.

[20] Sipkay, Cs., Kiss, K.T., Vadadi-Fülöp, Cs., Hufnagel, L. (2009): Trends in research on the possible effects of climate change concerning aquatic ecosystems with special emphasis on the modelling approach. - Applied Ecology and Environmental Research 7(2): 171-198.

[21] Tóthmérész, B. (1997): Diversity characterizations. - In: Zempléni A. (ed): Statistics at Universities: Its impact for society, Eötvös Univ Press pp. 107-113.

APPLIED ECOLOGY AND ENVIRONMENTAL RESEARCH 8(2): 119-130. http://www.ecology.uni-corvinus.hu • ISSN 15891623 (Print) • ISSN 17850037 (Online) (c) 2010, ALÖKI Kft., Budapest, Hungary 
[22] Tóthmérész, B. (2001): A short overview of measuring diversity. - Acta Pericemonologica 1: 150-164.

[23] Vadadi-Fülöp, Cs., Hufnagel, L., Sipkay, Cs., Verasztó, Cs. (2008a): Evaluation of climate change scenarios based on aquatic food web modelling - Applied Ecology and Environmental Research 6(1): 1-28.

[24] Vadadi-Fülöp, Cs., Mészáros, G., Jablonszky, Gy., Hufnagel, L. (2008b): The zooplankton of the Ráckeve-Sorokság Danube: Spatio-temporal changes and similarity patterns - Applied Ecology and Environmental Research 6(4): 119-145. 